\title{
Public relations in Portugal. An analysis of the profession through the undergraduate curriculum
}

\author{
Gisela Marques Pereira Gonçalves* \\ Communication and Arts Department, University of Beira Interior, Rua Marquês d'Avila e Bolama, 6200-001 Covilhã, Portugal ${ }^{1}$
}

\section{A R T I C L E I N F O}

\section{Article history:}

Received 13 December 2008

Received in revised form 15 April 2009

Accepted 2 May 2009

\section{Keywords:}

Public relations education

Undergraduate studies

Portugal

\begin{abstract}
A B S T R A C T
Higher education in public relations in Portugal has been expanding in recent years. The purpose of this research is to analyse undergraduate public relations programmes in Portugal within the Bologna Treaty reform. After having compared public relations curricula and defined the main features, an empirical research was applied in order to determine the opinion of public relations educators and practitioners about the ideal undergraduate plan of studies in public relations.
\end{abstract}

(C) 2009 Elsevier Inc. All rights reserved.

\section{Introduction}

The growing demand for PR/communication management specialists in Portuguese contemporary organizations has led to the expansion of undergraduate studies in public relations. The communication teaching boom really came about in the late eighties, with the proliferation of communication degrees called broadband. The communication sciences plan of studies is traditionally divided into two parts. One part, which is introductory, is centred on the interdisciplinary offer in the liberal arts and social sciences area and also on communication theory contents. The second curricular part is constituted by optional branches for which students can choose a more specific education in journalism, public relations, advertising or audio visual communication.

Recently, Portuguese higher education has been undergoing several modifications within the Bologna Treaty, which aims at establishing a European area for higher education formed by 45 countries by 2010. Taking into consideration the reformulation of the higher education plan of studies within the Bologna reform the question arises about the place that PR education can occupy in the new curriculums. In order to answer this question and to define the strengths and weaknesses in the teaching offered in the preparation of future practitioners, a research study was developed with regard to undergraduate studies in public relations. As such, the research was divided into two principal moments. In the first place, a comparative analysis of the 3 years plan of studies currently in force in Portugal was made and then, in second place, the perception of practitioners and educators was investigated as to the teaching provided.

\section{Undergraduate public relations programmes in Portugal}

A recent study by the Commission on Public Relations Education (2006), The Professional Bond, states that the ideal public relations major would include a minimum of five courses: (1) introduction to public relations (including theory, origin and

\footnotetext{
* Tel.: +351 275319 835/963185477 (Mobile); fax: +351 275319888.

E-mail address: gisela@ubi.pt.

1 http://www.ubi.pt.
} 
principles); (2) public relations research, measurement and evaluation; (3) public relations writing and production; (4) supervised work experience in public relations (internship); (5) an additional public relations course in law and ethics, planning and management, case studies or campaigns $(2006,47)$.

Different conclusions can be drawn from the comparison of the official objectives and programs of 18 curricular plans with regard to the offer in the five PR study areas recommended by the Commission on PR Education. Concerning (1) "introduction to PR" contents $94.4 \%$ of universities offer courses related to PR theory and history. (3) "Public relations writing and production" (100\%) and (5) "public relations planning and management" (88.8\%) contents are integrated in disciplines of a very practical nature (e.g., laboratories) which in most cases is reduced to one or two disciplines in the total curriculum. The content referring to "public relations research, measurement and performance evaluation" (83.3\%) can be found in subjects dedicated to "research methods". But it must be point out that these disciplines are not exclusively directed towards PR studies. Data also show that only 50\% of undergraduate programmes offer courses in (5) "PR law and ethics". However, those contents are always integrated in a more open course like "communication ethics or communication law". Finally, we must point out that only $50 \%$ of undergraduate studies offer (4) "supervised work experience in public relations".

Being aware that the conclusion of this analysis of curricular content are merely descriptive and for this same reason limited, it was decided to complement this reflection through an empiric study about the perception of educators and practitioners about higher education in public relations offered in Portugal.

\section{Perceptions about PR higher education}

\subsection{Methodology}

An exploratory study through a self-administered questionnaire via e-mail, between April and June 2007, was the method utilized to collect data about the opinion of practitioners and educators on PR teaching in Portugal. The filling in of a questionnaire was requested through access to a website created especially for the occasion. ${ }^{2}$ Fifty-seven percent of valid replies were obtained from a sample of 120 individuals, divided into 4 distinct groups: educators, company practitioners, public administration and communication consultancies. Due to the heterogeneity of professionals studied, the data obtained was handled through the comparison between the educator and the practitioner group. The practitioner group was subdivided into 3 subgroups whenever pertinent: companies, public administration and communication consultancies.

\subsection{Critical presentation of findings}

A list of 25 disciplines or central study areas for a higher education in public relations was created from the analysis of official curricular list in Portuguese curricula, following suggestions from the Commission on PR Education (2006) and from bibliographical revision. The questionnaire focuses on two fundamental issues: (1) what is the importance of each study area for higher PR education and (2) what is the relevance, which is currently given to each study area in higher education. Those questioned were challenged to classify the disciplines by their degree of importance and at the same time to give an opinion about the curricular relevance individually attributed to them in the current communication sciences/PR graduation.

(1) Through the analysis of the disciplines marked as "very or extremely important" with more than $50 \%$ replies it can be conclude that "issues management and crisis communication, media relations, strategic communication planning, internal communication" are the 4 study areas which are considered more important. "Foreign language, journalism and marketing" are the other disciplines that both educators and practitioners marked as priority. The consensus continues regarding the less important disciplines since both groups did not mark "radio/tv production; photography/cinema; design/graphics and new technology" as an important topic.

(2) In regard to the perception about the relevance which is in fact conceded to disciplines in current curricula, clear divisions of opinion can be noted, not only in the comparison of educator/practitioners, but especially between the different groups of practitioners. As an example, $58 \%$ of the educators, $68 \%$ of the consultancy practitioners, and $41 \%$ of public administration practitioners think that little importance has been attributed to the teaching of "issues management and crisis communication" whilst only $16 \%$ of the business practitioners are of the same opinion.

Apart from the "issues management and crisis communication", the disciplines in which one detects more displacement about their importance for PR education and the perception of the importance currently attributed to them in the higher education curricula are "political communication and lobby strategies". Data shows that $79 \%$ of the educators and $53 \%$ of the practitioners consider this content to be extremely important for PR higher education and that in parallel, $79 \%$ of the educators and $49 \%$ of the practitioners think that little importance has been attributed to them in current curricula.

\footnotetext{
2 http://www.inqueritos.ubi.pt/2007/.
} 


\section{Conclusions}

Through the study of current curricula in PR higher education in Portugal and from the opinion of educators and practitioners an attempt can be made to define their strengths and weaknesses in the preparation of future practitioners, not only from a pedagogical-scientific perspective but also from the point of view of the job market itself.

The large majority of PR higher education studies are integrated in communication sciences in Portugal, where studies in advertising and journalism are also included. This curricular dispersion limits the number of specific PR disciplines and most of the content taught within the PR perspective in the propaedeutic disciplines. This is a fact that conditions the importance of PR studies, whether theoretical or practical, in the communication sciences curriculum.

Naturally, the fact that the PR academic and scientific field is relatively new can explain the difficulty in defining the ideal curriculum. However, the results of the research applied to educators and practitioners corroborate the idea that PR studies do not occupy a very prominent position. Despite having consensual opinions about what is the ideal curricular content for PR undergraduate studies, those questioned stress the imperious necessity of attributing more importance to content like "issues management and crisis communication, lobby strategies and political communication".

Furthermore, the results of this study reveal that in Portugal PR undergraduate studies are compounded by strong education in communication studies but by insufficient education in PR. As such, the increase in the number of higher education courses which claim to offer PR education seem to represent the academic and scientific solidification of communication courses in the Portuguese university but not necessarily a consolidation of PR studies.

\section{Reference}

Commission on Public Relations Education. (2006). The professional bond-public relations education and the practice. New York: Public Relations Society of America. 